\title{
GRAFTING TECHNIQUE ONTO CUCURBIT ROOTSTOCKS FOR CONTROL SOIL BORN DISEASES AND ENHANCE THE PRODUCTIVE BEHAVIOR FOR MELON (CUCUMIS MELO) IN EGYPT
}

\author{
M.H. Zaki(1), Tomader G. Abd-el Raman(2) and Fahima H. Ayoub(1) \\ (1) Horticulture Res. Inst., Egypt. (2) Plant Pathology Res. Inst., Egypt.
}

Received: Nov. 27, 2017

Accepted: Dec. 27, 2017

\begin{abstract}
Two experiments were conducted at two successive seasons 2015/2016 and 2016/2017 during the activity of the project "Grafting techniques to improve production and to solve the problems in melon" under plastic greenhouse by supporting the Agriculture Development Programme in Egypt. The first experiment was conducted to evaluate two melon cultivars i.e., Hybrid London (Galia type) and Hybrid Magd (Ananas type) and eight cucurbit rootstocks for their resistance and/or susceptibility to soil borne diseases such as (Fusarium oxysporum and Verticillium albo-atrum) which considered the most serious pathogens that cause soil born diseases on melon crop. The data revealed that the Squash No3, Super Shintoza, Coplt, FliexFort, Ferro RZ, and Nun 6001 rootstocks were resistant to the $F$. oxysporum and $V$. albo-atrum pathogens in infested and non-infested soil except Pakistani luffa rootstock which was susceptible to the two pathogens. Moreover Squash No3, Ferro RZ, and Nun 6001 rootstocks are considered the highly resistant to F. oxysporum while Squash No3, FliexFort and Nun 6001 rootstocks are considered highly resistant to Verticillium albo-atrum. On the other hand the two tested melon varieties \{Hybrid London and Hybrid Magd\} were highly susceptible to the previous pathogens. The second experiment was conducted to compare between the effects of the previous resistant rootstocks and between three grafting methods (hole insertion grafting, splice grafting and tongue-approach grafting) on melon plant growth and yield components of Hybrid London compared with non-grafted plants which used as control. The highest success rate of grafted melon seedlings was recorded by tongue-approach grafting method followed by hole insertion grafting method. Moreover, the plants survival rate, vegetative growth characteristics (stem length, leaves number and shoot fresh weights), of grafting melon seedlings varied depending on grafting methods, rootstocks and the combination between grafting methods and rootstocks and difference between scion and rootstocks hypocotyls. The data revealed that the grafting onto Squash No3, Super Shintoza, Coplt, FliexFort, Ferro RZ and Nun 6001 rootstocks are suitable method for commercial melons production under greenhouse conditions in Egypt by provides sufficient protection against Fusarium oxysporum and Verticillium albo-atrum especially. This result due to the survival rate of plants grafted onto these rootstocks was extremely high. Moreover, the grafting melon seedlings by hole insertion and splice grafting methods onto FliexFort, Ferro RZ and Nun 6001 gave vigour growth, higher yield under greenhouse conditions without exhibiting any detrimental effects on melon fruit quality of the Hybrid London cultivar.
\end{abstract}

Key words: Rootstock; Scion; Hole insertion grafting; Splice grafting; Fusarium; Verticillium.

\section{INTRODUCTION}

Melon (Cucumis melo) is one of the most popular vegetables in Egypt. Melon plants are liable to be attacked by several soil pathogens, in particular Fusarium and Verticillium, which severely affected melon production (Martyn \& Gordon, 1996) and causing heavy economic losses in Egypt. This problem resulting in the fluctuation of cultivated areas and lead to some fields is no longer used for melon production. 
Therefore, farmers are required to shift for cultivating in the new land to avoid these diseases. However, these diseases have been spreading rapidly by inoculum transfer in soil on contaminated equipment and footwear, and particularly with transplants (Dau et al., 2009). Chemical control for these diseases mostly cause environmental pollution, increasing the accumulation of the toxic substances in human food chain and their application present a high cost in modern agriculture.

Grafting onto cucurbit rootstocks is a best alternative to control soil borne diseases and agronomic interest for plant vigor and production (Aounallah et al., 2002; Lee and Oda 2003; Rivero et al., 2003; Yetıs, Ir and Sari, 2003; Edelstein et al., 2004 and Tarchoun et al., 2005). This strategy for controlling Fusarium and verticilum wilt diseases has become more popular replacement for methyl bromide fumigation of soil (Besri 2008 and Bekhradi et al., 2011) especially in areas where land rotation is not feasible (Yetıs, Ir and Sari, 2003). Cucumis moschata and C. maxima $\times$ C. moschata rootstocks were later used in melon production to resist Fusarium wilt (Sakata et al., 2008). Also several researchers reported that several rootstocks have resistant to Fusarium wilt such as (C. maxima $\times$ C. moschata) i.e., Ferro rootstocks by Boughallebe et al. (2008), Cucurbita moschate rootstocks by Bithell et al. (2012) and Yetıs, Ir et al. (2003).

Mechanisms of diseases tolerance in grafted plants may be due to the resistance of the rootstocks as it is accepted that the root system synthesizes substances resistant to pathogen attack and these are transported to the shoot through the xylem (Biles et al., 1989). The activity of these substances, related to disease resistance can vary during the development stages of grafted plants (Heo, 1991). Also, Lee (1994) reported that the tolerance to the disease exhibited by grafted plants could be explained by their vigorous roots. In addition to disease resistance, the performance of the grafted plant depends on the compatibility of the rootstock with the scion, environmental conditions, and cultivation methods (Andrews and Marquez, 1993; Lee, 1994; Edelstein et al., 1999 and TrakaMavrona et al., 2000).

Grafting technique is effective directly on vegetative growth characteristics and plant yield (Traka- Mavrona et al., 2000; Bletos et al., 2003; Colla et al., 2006; Jang et al., 2008 and King et al., 2010). Bekhradi et al. (2011) reported that the grafting lead to increase the stem length of watermelon plants. Also, Paroussi et al. (2007), Cushman and Huan (2008) and Bekhradi et al. (2011), found that total soluble solid (TSS) was not affected by grafting. Moreover, grafting vegetable plants onto resistant rootstocks enhance whole plant biotic stress responses which lead to increase yield and fruit quality size (Rouphael et al., 2010). This influence can be explained by the interaction of various processes, such as: increased water and plant nutrient uptake (Kato and Lou 1989; Rivero et al., 2003) especially at low temperatures due to the rootstock vigorous root system (Lee, 1994 and Ruitz et al., 1997), enhancement of scion vigor (Leoni et al., 1990 and Ito 1991), improving the plants overall environmental efficiency (Lee, 1994; Lee and Oda, 2003 and Yetıs, Ir and Sari, 2003), tolerance to low soil temperature (Den Nijs and Smeets 1987and Tachibana, 1989) and salinity tolerance in the rootstocks (Rivero et al., 2003) and enhanced production of endogenous hormones (Zijlstra et al., 1994). 
Numerous rootstocks have been developed for melon grafted such as Lagernaria siceraria or to interspecific hybrids (C. maxima Duch. $\times$ C. moschata). The Cucurbita rootstock provides non-specific, but efficient protection from a wide range of soilborne diseases and against some abiotic stresses (Edelstein et al., 2004). The influences of rootstocks on fruit quality are vary greatly depending on the scion cultivars (Lee, 1994). On the other hand, the poor rootstock-scion compatibility may result in blocking the transport of photosynthesis from scion to rootstock for grafted melon, as reported by Stigter (1971). This can lead to yield reduction, poor fruit quality, and even early plant collapse (Andrews and Marquez, 1993; Lee, 1994; Edelstein et al., 2004 and Traka-Mavrona et al., 2000).

In Egypt there are several commercial rootstocks used for grafting watermelon and cucumber while limited information about these rootstocks on grafting melon for control soil borne diseases such as Fusarium and Verticillium wilt and their affected on melon growth, yield and fruit quality. Therefore, the aim of this study was to evaluate several cucurbit rootstocks for their resistant to soil borne diseases (Fusarium and Verticillium wilt) and compare the effects of different grafting methods, rootstocks on grafting success rate as well as to compare the differences in yield and growth of grafted plants with those of non-grafted plants.

\section{MATERIALS AND METHODS}

Two experiments were conducted in this study as following:

The first experiment: Rootstocks screening for resistance to Fusarium and Verticillium wilt.

This study was carried out in unheated greenhouse at Department of plant diseases (ARC) Giza during the two successive seasons i.e., 20/8/2015 and 22/8/2016. This study aimed to evaluate two melon cultivars i.e., Hybrid London (Galia type) and Hybrid Magd (Ananas type) and eight cucurbit species that will used as rootstocks (Table 1) for their resistance to soil borne diseases such as (Fusarium oxysporum and Verticillium albo-atrum) which considered the most serious pathogens that cause soil diseases for melon crop. All scions and rootstocks seedlings were transplanted into pots contained only one pathogen.

Table (1): The melon cultivars and cucurbit rootstocks that used in this experiment

\begin{tabular}{|c|c|c|c|}
\hline & Genotypes & Species & $\begin{array}{l}\text { Seed production } \\
\text { company }\end{array}$ \\
\hline \multirow{2}{*}{$\begin{array}{l}\text { Scion } \\
\text { Melon cultivar }\end{array}$} & Hybrid Magd & Cucumis melo L. & Rijk Zwaan \\
\hline & Hybrid London ME & Cucumis melo L. & Rijk Zwaan \\
\hline \multirow[t]{8}{*}{ Rootstock } & 1-Squash No3 & Cucurbita maxima & Sakata \\
\hline & 2-Super Shintoza & Cucurbita maxima $\times$ C. moschata & G.S.I \\
\hline & 3-FliexFort & Cucurbita maxima $\times$ C. moschata & Enza Zaaden \\
\hline & 4-Ferro RZ & Cucurbita maxima $\times$ C. moschata & Rijk Zwaan \\
\hline & 5-Nun 6001 & Cucurbita maxima $\times$ C. moschata & Nunhium \\
\hline & 6-Coplt & Cucurbita maxima $\times$ C. moschata & Rijk Zwaan \\
\hline & 7- Bottle gourd & Lagenaria siceraria & *HRI \\
\hline & 8- Pakistan luffa & Luffa cylindrica & Pakistan \\
\hline
\end{tabular}

*HRI: Horticultural Research Institute 


\section{a) Source of infection diseases}

This experiment used the fungi ( $F$. oxysporum and Verticillium albo-atrum) obtained from the fungi bank at the Plant Pathology Institute, A.R.C., Egypt for the infected the soil of melon cultivars which will used as scions and cucurbit rootstocks.

\section{b) Greenhouse experiments}

Pots $(25 \mathrm{~cm})$ were sterilized by dipping in $5 \%$ formalin for $5 \mathrm{~min}$ and then left in open air till dryness. Soil (sandy-loamy soil 1:1 v/v) sterilized with 5\% formalin, (I L./cubic Foot) mixed thoroughly, covered with plastic sheet for one week and then the plastic sheet was removed in order to complete formalin evaporation. Soil infestation with each individual fungus was carried out at the rate of $3 \%$ of soil weight. Inoculate were prepared by growing each fungus on sand barley (SB) medium ( $25 \mathrm{~g}$ clean sand $+75 \mathrm{~g}$ barley $+100 \mathrm{ml}$ water). Flasks contained sterilized medium were inoculated with each particular fungus and incubated at $25^{\circ} \mathrm{C}$ for two weeks.

The pots planting with cucurbit rootstocks or melon cultivars seedlings which were divided into three groups. The first group was inoculated with Fusarium oxysporum, the second group was inoculated with Verticillium alboatrum and the third group served as control plant (un-inoculated). Soil of control pots was mixed with the same amount using sterilized sand- barley (SB) medium. Potted soil was watered daily for a week to enhance the fungal growth. The pots were arranged in a completely randomized design with three replicates in greenhouse for 30 days and then 30 plants were evaluated from each replicate from each treatment. Plants were watered as needed and no fertilizers were applied. Evaluation of disease severity was carried out according to disease symptoms on leaf, vascular discoloration and wilting using the scale proposed by Kesevan and Chounhury (1977). The used scale was:

0 . No disease symptoms. $(\mathrm{HR}=$ Highly Resistant)

1. less than $25 \%$ of leaves with disease symptoms.( $R=$ Resistant)

2. 25 to $50 \%$ of the leaves showing chlorosis. ( $M=$ Moderate)

3. 51 to $75 \%$ of the leaves showing chlorosis and / or stunting of some plants. ( $\mathrm{S}=$ Susceptible)

4. 76 to $100 \%$ chlorosis accompanied or not with both defoliation or with stunting. (HS= Highly Susceptible)

Disease index $=\Sigma(f X v) / n x \times 100$

$\mathrm{f}=$ frequency of a numerical rating.

$v=$ numerical rating of the scale (0-4).

$\mathrm{N}=$ total number of tested plants.

$X=$ maximal value (4) of the evaluation scale.

\section{Statistical analysis:}

All obtained data were recorded on plot basis and statistically analyzed according to the randomized complete block design in factorial arrangement using Duncan's Multiple Range Test at $5 \%$ level to compare between treatment means as described by Gomez and Gomez (1984).

\section{The second experiment Grafting experimental design}

Grafting experiment was conducted at Kaha Research Station Kalubia governorate, Egypt under plastic greenhouse during the two successive seasons of 2/10/2015 and 6/10/2016. This experiment aimed to study the effect of different seven cucurbit rootstocks and three grafting methods on melon plant growth and yield components compared with non-grafted plants which used as control. The used rootstocks in this study were found to be 
resistant and moderately resistant ones to both $F$. oxysporum and Verticillium albo-atrum from a previous experiment they were Squash No3, Super Shintoza, Nun 6001, Ferro RZ, FliexFort, Coplt and Bottle gourd. Melon (Cucumis melo) seedlings Hybrid London (Galia type) was used as scion. All the melon scions and rootstocks seeds were sown under unheated greenhouse in plug trays (cell volume: $50 \mathrm{~mL}$ ) contained peat moss, vermiculite and perlite mixture in a ratio of $1: 1: 1(\mathrm{v} / \mathrm{v} / \mathrm{v})$. Scion (melon) seeds were planted five days after rootstocks to ensure the same stem diameter of scion and rootstocks hypocotyls to be suitable for the grafting method.

Grafting: Melon seedlings (used as scion) were grafted onto different rootstocks 10 days after their planting in a shaded area under greenhouse. Three different grafting methods, hole insertion grafting (HIG), splice grafting (SP) and tongue-approach grafting (TAG) were compared. These were performed according to the method of Oda et al. (1993).

Healing and acclimation: Grafted plants were transferred to plastic tunnel covered with two layers of black shade nets with $72 \%$ shade to reduce light intensity. Grafted plants were kept under dark conditions for the first two days following grafting. Humidity was gradually decreased from $95-100 \%$ to $75-80 \%$ for seven days starting on the third day, while the intensity of light was increased. The mean daily temperature in the plastic tunnel ranged between 22 and $26^{\circ} \mathrm{C}$. Ten days after grafting, plants were transferred to a greenhouse, and appropriate shading was applied for adaptation of grafted plants.

Planting: Grafting seedlings and nongrafted control plants were transplanted after 10 days from adaptation in the plastic greenhouse. The treatments were arranged in split plot design with 3 replicates where the seven previous rootstocks distributed in the main plots and the three grafting methods occupied the sub-plot. Each replicate consisted of 15 plants. The grafted and non- grafted plants were transplanted on raised beds $1 \mathrm{~m}$ wide and $50 \mathrm{~cm}$ apart spacing between rows and between plants, and grown horizontally in greenhouse. Moreover, training was applied to the grafted and non-grafted melon seedlings after transplanting to produce 3 lateral branches and 3 fruits. All cultural operations were similar to those practiced in commercial greenhouse production.

\section{Studied characteristics:}

The following vegetative and qualitative traits were recorded:

\section{Determination of grafting success rate:}

On the day of planting (27 days after grafting), the number of grafts that survived was counted, and grafting success rate was determined as a percentage of the total grafting plants (100 plants for each treatment).

\section{Determination of plants survival rates:}

Survival rates were measured after 60 days from transplanting in each replicates of each treatment by account the successful grafted seedlings and dividing it with the total number of the grafted planting seedlings.

\section{Scion and rootstock hypocotyls diameter (cm):}

Scion and rootstock hypocotyls diameter were determined at planting and 60 days after transplanting. The average diameters of the hypocotyls at the grafting site were measured with a micrometer.

\section{Determination of grafting performance}

4.1. Vegetative growth characteristics:

Vegetative growth characteristics were recorded in samples of four plants randomly chosen from each plot as follows: 
M.H. Zaki, et al.,

4.1.2. Stem length $(\mathrm{cm})$

4.1.3. Number of leaves/plant.

4.1.4. Fresh weight of shoot $(\mathrm{g})$

\subsection{Fruit characteristics:}

Hybrid London was harvested at fullslip stage to determine the fruit characteristics during early harvests by measuring the following: 1) fruit length $(\mathrm{cm}), 2)$ fruit diameter $(\mathrm{cm}), 3)$ average fruit weight $(\mathrm{kg})$ that was calculated by dividing all over the harvesting fruit weight on fruit number, 4) total soluble solids (TSS\%) that were measured in fruit juice using a hand refractometer. Three typical fruit per treatment were taken at random in each replication were selected to measure the previous fruit characteristics.

\subsection{Yield components:}

The following traits were evaluated

4.3.1. Early yield ( $\mathrm{Kg} /$ plant): It was estimated as the weight of fruits/plant of first and second harvesting.

4.3.2. Total yield ( $\mathrm{Kg} /$ plant): It was estimated as total weight of the harvested fruits throughout the entire season in $\mathrm{kg}$ per plant.

\section{Statistical analysis:}

The obtained data were subjected to the analysis of variance procedure and means compared using the L.S.D. method at $5 \%$ level of significance according to Gomez and Gomez (1984).

\section{RESULTS}

\section{The first experiment \\ Evaluation of the severity of infection \\ Evaluation of rootstocks resistance}

The inoculation of the egiht cucurbits rootstocks revealed differences in severily of infection $F$. oxysporum and Verticillium albo-atrum tested in this study which cause damping- off of seedlings and vascular wilt (Table, 2). Data revealed that all the cucurbit rootstocks in this study were resistant to $F$. oxysporum and Verticillium alboatrum in infested and non-infested soil except Pakistani luffa rootstock which was susceptible to the two pathogens. Moreover, data showed also that the Cucurbita maxima rootstock, i.e. Squash No3 and the two interspecific hybrids rootstocks (Cucurbita maxima $x$ Cucurbita moschata) i.e. Ferro RZ, and Nun 6001 were considered highly resistant or resistant to $F$. oxysporum with no significant differences between them. However, the other interspecific hybrids rootstocks (Super Shintoza, FliexFort, Coplt) and the local Bottle gourd were moderately resistant to this pathogen. These results agreed with Sakata et al. (2008) who reported that C. moschata and C. maxima $\times C$. moschata rootstocks were later used in melon production to control Fusarium wilt. Also several researchers reported that several rootstocks have resistant to Fusarium wilt such as (C. maxima $\times C$. moschata) i.e., Ferro rootstocks (Boughalleb et al., 2008) and Cucurbita moschate rootstocks (Bithell et al., 2012 and Yetıs, Ir et al., 2003).

Considering the inoculation of the cucurbits rootstocks with Verticillium albo-atrum data in Table (2) showed that the Cucurbita maxima rootstock, i.e. Squash No3 and the three interspecific hybrids rootstocks i.e. FliexFort and Nun 6001 are considered highly resistant or resistant to Verticillium albo-atrum with no significant differences between them. At the same time, the other interspecific hybrids rootstocks (Super Shintoza, Ferro RZ, Coplt) and the local Bottle gourd showed an intermediate behavior and was moderately resistant to this pathogen. 
Table (2): Severity of infection \% in melon cultivars and tested rootstocks with $F$. oxysporum and $V$. albo-atrum under greenhouse conditions.

\begin{tabular}{|c|c|c|c|c|c|c|c|}
\hline \multirow{2}{*}{\multicolumn{2}{|c|}{ Genotype }} & \multicolumn{3}{|c|}{ First season } & \multicolumn{3}{|c|}{ Second season } \\
\hline & & \multirow{2}{*}{$\begin{array}{c}\text { F.oxsporum } \\
25.0^{c}\end{array}$} & \multirow{2}{*}{$\begin{array}{c}\begin{array}{c}\text { V. } \\
\text { albo- } \\
\text { atrum }\end{array} \\
13.0^{c}\end{array}$} & \multirow{2}{*}{$\begin{array}{l}\text { Control } \\
00.0^{b}\end{array}$} & \multirow{2}{*}{$\begin{array}{c}\text { F.oxsporum } \\
22.0^{\mathrm{d}}\end{array}$} & \multirow{2}{*}{$\begin{array}{c}\begin{array}{c}V . \\
\text { albo- } \\
\text { atrum }\end{array} \\
15.0^{d}\end{array}$} & \multirow{2}{*}{$\begin{array}{c}\text { Control } \\
00.0^{b}\end{array}$} \\
\hline Rootstock & Squash No3 & & & & & & \\
\hline & $\begin{array}{l}\text { Super } \\
\text { Shintoza }\end{array}$ & $33.0^{b}$ & $45.0^{\mathrm{b}}$ & $00.0^{b}$ & $32.0^{c}$ & $33.0^{c}$ & $00.0^{b}$ \\
\hline & Coplt & $31.0^{b}$ & $32.0^{\mathrm{b}}$ & $00.0^{b}$ & $43.0^{b}$ & $40.0^{b}$ & $00.0^{b}$ \\
\hline & FliexFort & $36.0^{b}$ & $24.0^{c}$ & $00.0^{b}$ & $25.0^{d}$ & $25.0^{d}$ & $00.0^{b}$ \\
\hline & Ferro RZ & $23.0^{\mathrm{c}}$ & $33.0^{\mathrm{b}}$ & $00.0^{b}$ & $22.0^{d}$ & $34.0^{c}$ & $00.0^{b}$ \\
\hline & Nun 6001 & $30.0^{c}$ & $25.0^{c}$ & $00.0^{b}$ & $24.0^{d}$ & $28.0^{d}$ & $00.0^{b}$ \\
\hline & Bottle gourd & $32.0^{b}$ & $33.0^{\mathrm{b}}$ & $00.0^{b}$ & $44.0^{b}$ & $35.0^{c}$ & $00.0^{b}$ \\
\hline & Pakistani Loof & $77.0^{\mathrm{a}}$ & $85.0^{a}$ & $10.3^{a}$ & $80.0^{a}$ & $87.0^{a}$ & $11.3^{a}$ \\
\hline \multirow[t]{2}{*}{ Melon } & Hybrid Magd & $80.0^{a}$ & $88.0^{a}$ & $10.5^{\mathrm{a}}$ & $88.0^{a}$ & $89.0^{a}$ & $9.5^{\mathrm{a}}$ \\
\hline & $\begin{array}{l}\text { Hybrid } \\
\text { London ME }\end{array}$ & $85.0^{a}$ & $100.0^{a}$ & $10.7^{a}$ & $90.0^{a}$ & $96.0^{a}$ & $10.1^{a}$ \\
\hline
\end{tabular}

The values followed by the same letter are not significantly different at $p<5 \%$. The results have been done after 15 days from planting in the infested soil.

\section{Evaluation of melon cultivars resistance}

The inoculation of the two melon cultivars revealed a meaningful differences against $F$. oxysporum and Verticillium albo-atrum tested in this study which cause damping- off of seedlings and vascular wilt. Data in Table (2) showed that the two tested melon varieties (Hybrid Magd and Hybrid London) were highly infected with $F$. oxysporum and Verticillium alboatrum with no significant differences between them in both infested and noninfested soil.

\section{The second experiment Grafting experimental}

\section{Grafting success rate}

The variations in the grafting success rate due to the grafting methods onto different rootstocks in melon seedlings are shown in Table (3). The results clear that the percentage of success rate after 27 days from grafting melon varied depending on grafting methods, rootstocks and the combination between grafting methods and rootstocks. The grafting success rate ranged from 84.2 $\%$ to $93.3 \%$ and $85.6 \%$ to $95.0 \%$ during the first and second season respectively due to the different grafting method. Data showed high success rate of grafted melon seedlings in tongueapproach grafting method followed by hole insertion grafting method during the two studied seasons. This result indicated that the tongue approach and hole insertion grafting methods are the most suitable grafting techniques for increasing the grafting success rate in melon seedlings. This result may be due to remain the root of the scion until the formation of the graft union in the tongue approach grafting, and the lower cut surface in contact in hole insertion 
M.H. Zaki, et al.,

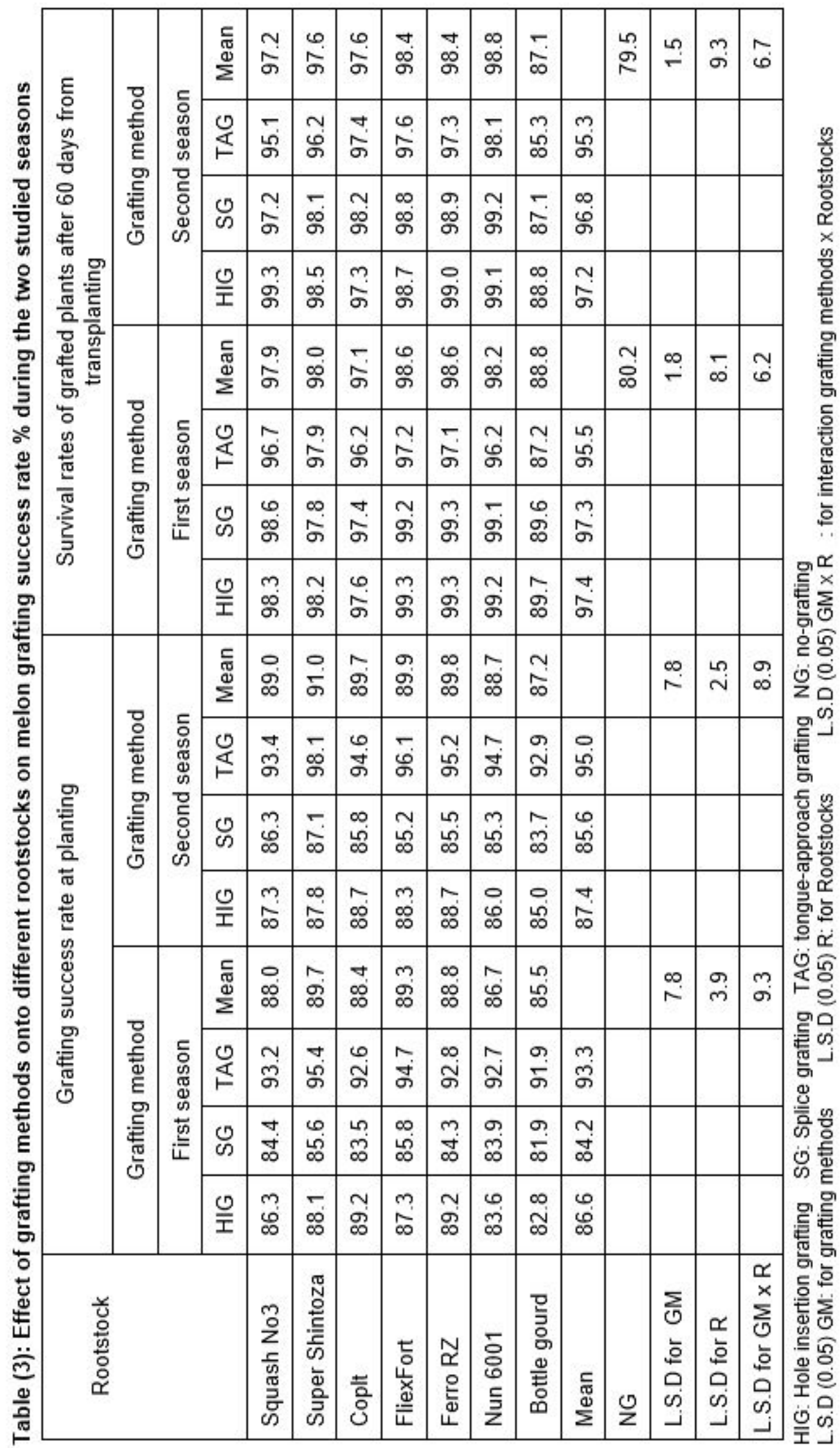


grafting method as reported by Bekhradi et al. (2011). On the other hand the lowest grafting success rate of melon seedlings was recorded on splice grafting method. This result may be due to the larger cut surface in contact which allow more transpiration and water loss in this method as reported by Bekhradi et al. (2011). At the same time, the grafting success rate ranged from $85.5 \%$ to $89.7 \%$ and $87.2 \%$ to $91.0 \%$ during the first and second seasons respectively due to different rootstocks for grafting melon seedlings.

Data showed also that the grafting melon seedlings onto Squash No3, Super Shintoza, Coplt, FliexFort, Ferro RZ, and Nun 6001 rootstocks gave the highest significantly success rate of grafting. While, the grafting onto local bottle gourd gave the lowest value. The highest grafting success rate in the previous rootstocks when compared to the local bottle gourd may related to the hypocotyl diameter of the rootstocks and, to a lesser extent, to the scion diameter as shown in Table (4).

Concerning grafting methodrootstock interaction data revealed also that the grafting melon onto all studied rootstocks with use tongue approach grafting methods gave the highest grafting success rate compared to the other grafting method- rootstock combination.

\section{Plant survival rate}

The results of plant survival rate (after 60 days from transplanting) in response to the grafting methods onto different rootstocks compared to ungrafted plants of melon seedlings are shown in Table (3). Data indicate that all the grafting melon plants with different grafting methods gave higher plant survival rate than un-grafted plants. These results indicate that grafting melon plants onto all the previous resistant rootstocks is an effective tool that may enable the susceptible scion to control soil-borne diseases under natural infection conditions and lead to increase the plant survival rate compared to the un-grafted melon plants. These results explained that when there are no differences in the stem diameter between the rootstocks and scion lead to increase the survival rate of grafting plants as reported by Traka-Mavrona et al., (2000). Moreover the differences in plant survival may be attributed to climatic conditions and to rootstock vigor (Andrews and Marquez, 1993; Edelstein et al., 1999; Lee, 1994; Lee et al., 1998; Oda, 1999; Oda et al., 2000; Traka-Mavrona et al., 2000), relation to both rootstock and scion (Traka-Mavrona et al., 2000), growth rate before grafting, tissue age, wetness of cut area, cut surface in the contact, pressure between cut area and number of vascular bundle in contact (Oda et al., 2000 and Leonardi and Romano, 2004), compatibility of the rootstock with the scion (Andrews and Marquez, 1993; Edelstein et al., 1999; Lee, 1994; TrakaMavrona et al., 2000). At the same time the mechanisms of diseases tolerance in grafted plants may be due to the resistance of the rootstocks as it is accepted that the root system synthesizes substances resistant to the pathogen attack and these are transported to the shoot through the xylem (Biles et al., 1989). The activity of these substances, related to disease resistance can vary during the development stages of grafted plants (Heo, 1991). Also, Lee (1994) reported that the tolerance to the disease exhibited by grafted plants could be explained by their vigorous roots.

The results showed also that the plant survival rate in melon plants after 60 days from transplanting varied depending on grafting method, rootstock, the combination between 
M.H. Zaki, et al.,

grafting method and rootstock and differences between scion and rootstocks hypocotyls as shown in Table (4).

The highest plant survival rate of grafted melon plants was found in hole insertion grafting method compared with the tongue-approach grafting and splice grafting methods during the two studied seasons. This result indicate that the hole insertion grafting methods is the best grafting technique (among the other tested methods) for increasing the plant survival rate in melon plants. This result are in agreement with Bekhradi et al, (2011) because of the lower cut surface in contact, while the lowest survival rate in the splice grafting method may be due to the larger cut surface in contact and more water loss by transpiration in this method.

The results showed that plant survival rates varied depending on rootstock. The highest value of plant survival rates was recorded in grafting onto Squash No3, Super Shintoza, Coplt, FliexFort, Ferro RZ, and Nun 6001 rootstocks with no significant differences between them while, the lowest value was recorded in grafting onto local bottle gourd. This result may be related to the hypocotyl diameter of the rootstocks and, to a lesser extent, to the scion diameter as shown in Table (4). Moreover, the mechanisms involved in these different responses for survival rate are related to growth rate before grafting, tissue age, climatic conditions, rootstock leaf area, wetness of cut area, cut surface in contact area, pressure between cut area and number of vascular bundles in the same area as reported by (Oda et al., 1993; Oda et al., 2000). Moreover, the obtained data showed that the local bottle gourd is unsuitable rootstocks for the grafting of the melon (cultivar Hybrid London), which resulted in lower of plant survival rates. This result indicate that there are weak compatibility between the melon plants (cultivar Hybrid London) and the local bottle gourd rootstock which may result in blocking the transport of photosynthesis from scion to rootstock for grafted melon, as reported by Stigter (1971). This can lead to early plant collapse as reported by (Andrews and Marquez, 1993; Edelstein et al., 2004; Lee, 1994; Traka-Mavrona et al., 2000).

Concerning the grafting methodrootstock interaction data revealed also that the hole insertion grafting method, splice grafting method and tongueapproach grafting method gave the highest plant survival rates in grafting onto Squash No3, Super Shintoza, Coplt, FliexFort, Ferro RZ, and Nun 6001 rootstocks. On the other hand, all the grafting methods with local Bottle gourd as rootstock gave the lowest value under greenhouse conditions. These results indicate that only the scion/rootstock combination can ensure high survival rate. Therefore the local bottle gourd rootstock had less compatibility for melon grafting.

\section{Scion and rootstock hypocotyls diameter}

The variations in the scion and rootstock hypocotyls diameter due to the use of different grafting methods onto different rootstocks in melon seedlings are shown in Table (4). Concerning the scion and rootstock hypocotyls diameter at planting grafted seedlings the results showed that the grafting methods did not affect on scion and rootstocks hypocotyls diameter.

At the same time the rootstocks did not affect on scion hypocotyl diameter. Results indicate also that all grafting melon plants onto Squash No3, Super Shintoza, Coplt, FliexFort, Ferro RZ, and Nun 6001 rootstocks, caused significant 
Grafting technique onto cucurbit rootstocks for control soil born

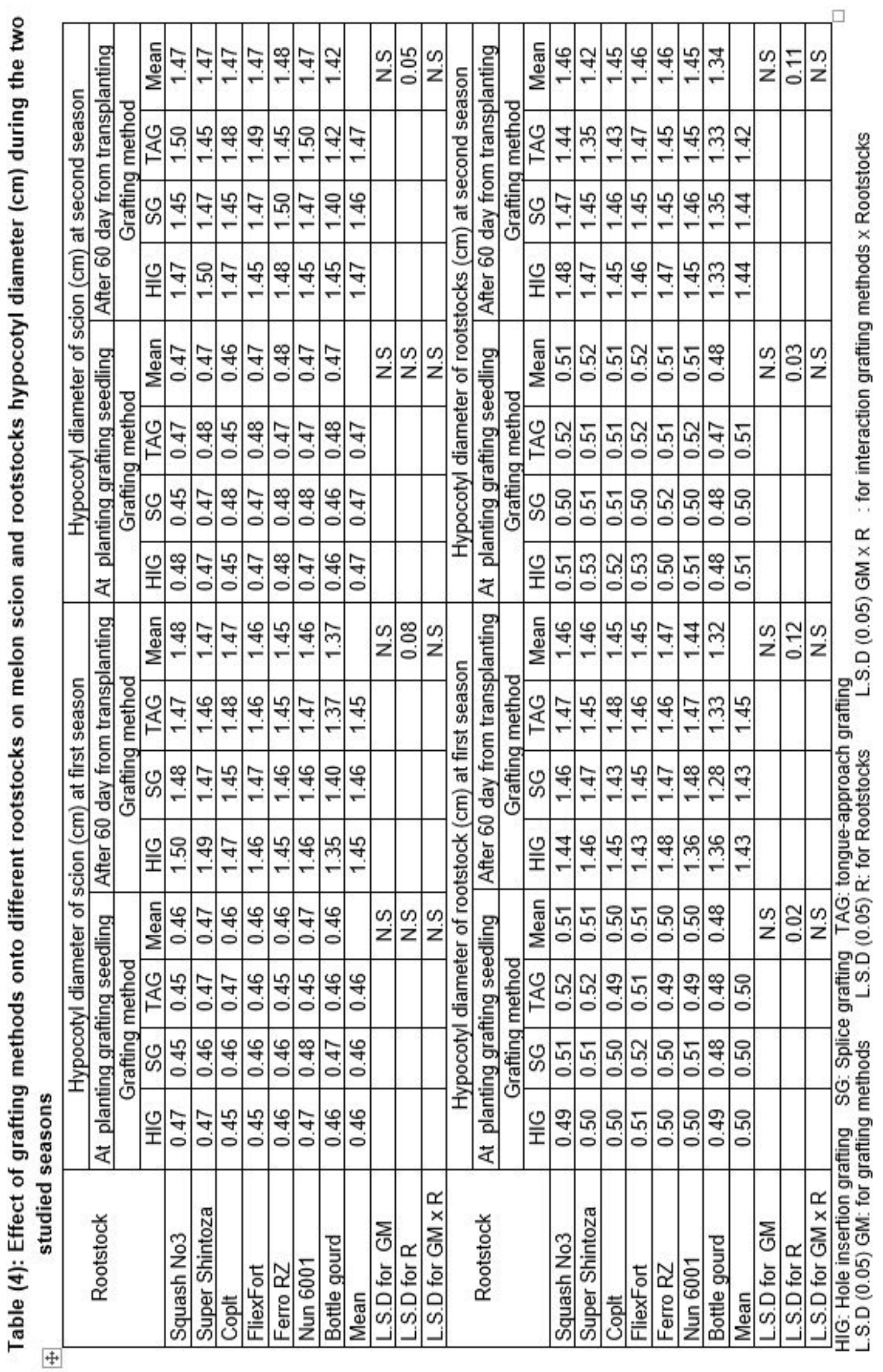


increase in rootstocks hypocotyls diameter with no differences between them while grafting melon plants onto local Bottle gourd caused the lower rootstocks hypocotyls diameter.

Data showed that there were no differences due to the grafting methodrootstock interaction on scion and rootstock hypocotyls diameter at the planting grafting seedlings. These results may be lead to increase the survival rate of grafts. These results are in harmony with Traka-Mavrona et al. (2000) who reported that the differences in stem diameter between Cucurbita and Cucumis reduce the survival rate of grafts.

\section{Grafting performance}

\subsection{Vegetative growth characteristics}

The variations in vegetative growth characteristics (stem length, leaves number and shoot fresh weights) of grafting melon seedlings due to the grafting methods onto different rootstocks are shown in Tables (5 and $6)$. The results show that all vegetative growth performance of grafting melon varied depending on grafting methods, rootstocks and the combination between grafting methods and rootstocks.

The vegetative growth performance (stem length, leaves number and shoot fresh weights) examined in this study were significantly enhanced in grafting melon seedlings comparison with the un-grafted control plants. These results indicate that grafting melon plants onto resistant rootstocks is an effective tool that may enable the susceptible scion to control soil-borne diseases, enhance whole plant biotic stress responses which lead to increase the plant growth. These results agree with those of Aounallah et al. (2002); Lee and Oda (2003); Rivero et al. (2003); Yetisir and Sari, (2003); Edelstein et al. (2004) and Tarchoun et al. (2005) who reported that the grafting is best agronomic interest for plant vigour. Also they are in harmony with Bletos et al. (2003); Colla et al. (2006); King et al. (2010), Jang et al. (2008); Traka-Mavrona et al. (2000) who reported that grafting technique is effective directly on vegetative growth characteristics.

Data showed higher vegetative growth performance of grafting melon seedlings in hole insertion grafting method followed by splice grafting method while the lowest value was recorded on tongue approach grafting method during the two studied seasons. These results indicate that these grafting methods are the best grafting technique for increasing the vegetative growth performance in melon grafting plants.

Results indicate that grafting melon plants onto Squash No3, Super Shintoza, Coplt, FliexFort, Ferro RZ and Nun 6001 rootstocks caused significant increase in vegetative growth performance while grafting onto local bottle gourd gave the lowest value. These results indicate that vegetative growth performance of melon grafted is influenced by rootstock. Moreover all the previous rootstocks gave more vigorous when grafted on melon plants than the local bottle gourd rootstocks under greenhouse condition. These results may be attributed to the strength roots of rootstocks that permit better growth. This result indicates that the grafting promotes vegetative growth performance depending on rootstock characteristics which will lead to increased vigor of the aerial parts. This is consistent with Ruiz et al. (1996), who mentioned that the more vigor root system is, the more phosphorus and other minerals uptake by the root and this will lead eventually to higher carbohydrate synthesis in the shoot system and thereby increase the growth of the aerial parts of the plant. Moreover, 


\begin{tabular}{|c|c|c|c|c|c|c|c|c|c|c|c|c|c|c|c|}
\hline \multirow{8}{*}{ 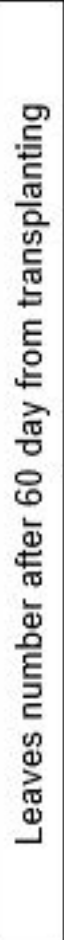 } & \multirow{4}{*}{ 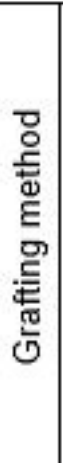 } & \multirow{4}{*}{ 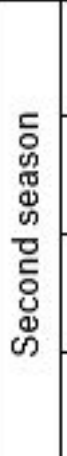 } & 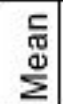 & \begin{tabular}{l|} 
\\
सें
\end{tabular} & ले & $\begin{array}{l}0 \\
\text { ले }\end{array}$ & $\begin{array}{l}\text { ले } \\
\text { से }\end{array}$ & $\begin{array}{l}\text { Ln } \\
\text { सें }\end{array}$ & छे & 官 & & \begin{tabular}{|l|}
$n$ \\
0 \\
0 \\
\end{tabular} & $\stackrel{\bullet}{\sim}$ & $\stackrel{\sigma}{i}$ & $\bar{m}$ \\
\hline & & & $\stackrel{0}{\mathbb{T}}$ & लें & స̃ & $\stackrel{0}{m}$ & $\stackrel{\circ}{\text { లె }}$ & $\stackrel{\varphi}{m}$ & $\underset{m}{N}$ & $\begin{array}{l}\text { Ln } \\
\text { ồ }\end{array}$ & $\frac{\sigma}{m}$ & & & & \\
\hline & & & 心 & $\begin{array}{l}n \\
\mathrm{~L} \\
\mathrm{~m}\end{array}$ & $\begin{array}{l}\infty \\
\stackrel{m}{m}\end{array}$ & 佮 & $\stackrel{\sim}{\tilde{m}}$ & 宊 & 슬 & $\hat{\bar{m}}$ & $\begin{array}{l}n \\
\tilde{m}\end{array}$ & & & & \\
\hline & & & 呈 & in & $\begin{array}{l}\omega \\
\stackrel{\omega}{m} \\
\end{array}$ & $\underset{\text { ले }}{-}$ & $\begin{array}{l}\infty \\
\stackrel{\infty}{m}\end{array}$ & $\begin{array}{l}\infty \\
\stackrel{\text { L }}{ }\end{array}$ & 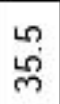 & $\begin{array}{l}\text { g. } \\
\text { लें }\end{array}$ & $\begin{array}{l}\infty \\
\text { mें }\end{array}$ & & & & \\
\hline & & & 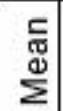 & ले & ö & $\begin{array}{l}\dot{v} \\
\text { ले }\end{array}$ & लें & $\stackrel{m}{m}$ & $\stackrel{\vec{m}}{\forall}$ & $\begin{array}{l}\infty \\
\\
\end{array}$ & & $\frac{0}{m}$ & $\underset{N}{N}$ & $\stackrel{+}{\sim}$ & $\hat{\mathrm{N}}$ \\
\hline & 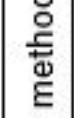 & 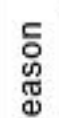 & 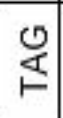 & స̄ & - & r. & 户্ল & 高 & సั่ & $\begin{array}{l}\text { न } \\
\text { में }\end{array}$ & 을 & & & & \\
\hline & 豪 & 苞 & O্ & $m$ & $m$ & $\begin{array}{l}\tilde{m} \\
\tilde{m}\end{array}$ & 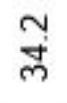 & 宛 & 宛 & 占 & $m$ & & & & \\
\hline & & & $\stackrel{0}{\text { 至 }}$ & $\begin{array}{l}\infty \\
\ddot{m}\end{array}$ & in & in & 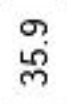 & $\begin{array}{l}\infty \\
\text { ले }\end{array}$ & $\begin{array}{l}\text { 이 } \\
\text { ले }\end{array}$ & 울 & 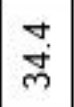 & & & & \\
\hline & & & 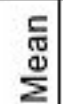 & $\underset{\mathrm{N}}{\stackrel{\Sigma}{*}}$ & $\stackrel{m}{\tilde{g}}$ & $\begin{array}{l}\infty \\
\stackrel{N}{N}\end{array}$ & 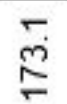 & $\stackrel{m}{N}$ & $\begin{array}{l}\hat{N} \\
\stackrel{n}{F}\end{array}$ & $\begin{array}{l}m \\
\infty \\
\infty \\
\stackrel{0}{c}\end{array}$ & & 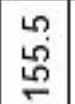 & $\bar{\sigma}$ & $\stackrel{N}{=}$ & $\hat{\sigma}$ \\
\hline $\begin{array}{l}\text { D } \\
\text { 䇏 } \\
\text { 픙 }\end{array}$ & 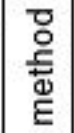 & 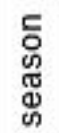 & $\begin{array}{l}0 \\
\mathbb{\Xi} \\
\vdash\end{array}$ & $\begin{array}{l}m \\
0 \\
0 \\
\end{array}$ & $\begin{array}{l}m \\
\tilde{\varphi} \\
\sigma\end{array}$ & $\begin{array}{l}\infty \\
\Phi \\
\varrho \\
\varnothing\end{array}$ & $\begin{array}{l}\infty \\
\stackrel{\infty}{0} \\
\stackrel{0}{\circ}\end{array}$ & $\stackrel{\infty}{\stackrel{\omega}{0}}$ & 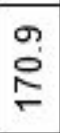 & 范 & $\begin{array}{l}m \\
\stackrel{m}{\sigma} \\
\stackrel{n}{-}\end{array}$ & & & & \\
\hline $\begin{array}{l}\sqrt[5]{\tilde{N}} \\
\stackrel{\mathbb{W}}{=} \\
E\end{array}$ & 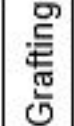 & 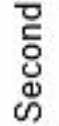 & O & $\begin{array}{l}n \\
\tilde{N} \\
=\end{array}$ & $\begin{array}{l}\infty \\
\infty \\
\infty \\
\Gamma \\
\end{array}$ & $\begin{array}{l}m \\
\infty \\
⿱ 乛 \\
-\end{array}$ & $\stackrel{\infty}{\stackrel{2}{2}}$ & $\begin{array}{l}m \\
\stackrel{2}{R}\end{array}$ & $\begin{array}{l}0 \\
\infty \\
\stackrel{\infty}{\sigma} \\
=\end{array}$ & $\begin{array}{l}m \\
\tilde{m} \\
\tilde{n}\end{array}$ & $\begin{array}{l}n \\
0 \\
0 \\
0\end{array}$ & & & & \\
\hline $\begin{array}{l}\text { 은 } \\
\frac{\pi}{3}\end{array}$ & & & 呈 & 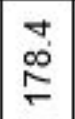 & $\stackrel{\infty}{\Sigma}$ & $\begin{array}{l}m \\
\stackrel{2}{=} \\
\end{array}$ & $\begin{array}{l}\infty \\
\infty \\
\stackrel{\infty}{\circ}\end{array}$ & 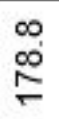 & $\stackrel{0}{\Sigma}$ & $\begin{array}{l}m \\
\dot{U} \\
\underline{0}\end{array}$ & $\begin{array}{l}\text { o } \\
\text { N } \\
\end{array}$ & & & & \\
\hline 怘 & & & $\begin{array}{l}\text { c } \\
\mathbb{d} \\
\stackrel{d}{\Sigma}\end{array}$ & 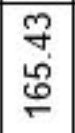 & \begin{tabular}{|l|} 
\\
ㅇ \\
0 \\
0 \\
0
\end{tabular} & \begin{tabular}{|l|} 
\\
0 \\
0 \\
0
\end{tabular} & 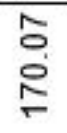 & 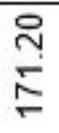 & 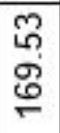 & $\begin{array}{l}\text { 음 } \\
\text { 변 } \\
\end{array}$ & & $\begin{array}{c}0 \\
\stackrel{\omega}{n} \\
\sim\end{array} \mid$ & m & $\omega_{\infty}^{\infty}$ & $\stackrel{\infty}{\sim}$ \\
\hline $\begin{array}{l}\text { 를 } \\
\text { 奇 }\end{array}$ & $\begin{array}{l}\text { 모 } \\
\text { İ } \\
\text { Е }\end{array}$ & 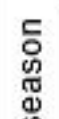 & \begin{tabular}{|l|}
0 \\
\\
\end{tabular} & $\begin{array}{l}\tilde{O} \\
0 \\
0\end{array}$ & $\begin{array}{l}0 \\
0 \\
0 \\
\end{array}$ & $\begin{array}{l}m \\
\tilde{m} \\
\tilde{w}\end{array}$ & $\check{0}$ & $\begin{array}{l}m \\
\infty \\
\stackrel{0}{\circ}\end{array}$ & $\begin{array}{l}+ \\
\stackrel{0}{\circ}\end{array}$ & $\begin{array}{l}\sim \\
\dot{\Delta} \\
\leftarrow\end{array}$ & $\begin{array}{l}\hat{\sigma} \\
\stackrel{\sigma}{\leftarrow}\end{array}$ & & & & \\
\hline $\begin{array}{l}\frac{\underline{U}}{\bar{E}} \\
\frac{\mathrm{J}}{\omega}\end{array}$ & 蜜 & 莗 & 心 & $\begin{array}{l}0 \\
0 \\
0 \\
\end{array}$ & $\begin{array}{l}m \\
0 \\
\emptyset\end{array}$ & 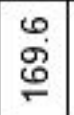 & $\begin{array}{l}\infty \\
\stackrel{0}{0}\end{array}$ & $\stackrel{m}{\stackrel{m}{\Omega}}$ & $\stackrel{2}{2}$ & $\begin{array}{l} \pm \\
\text { กิ่ } \\
\end{array}$ & $\begin{array}{l}0 \\
\ddot{0} \\
\varrho \\
\end{array}$ & & & & \\
\hline & & & 号 & $\begin{array}{l}\sim \\
\stackrel{\sigma}{\sigma} \\
\mathscr{\sigma}\end{array}$ & $\begin{array}{l}m \\
\infty \\
\infty \\
=\end{array}$ & $\begin{array}{l}m \\
\stackrel{m}{N} \\
=\end{array}$ & $\stackrel{m}{\stackrel{m}{\rightleftharpoons}}$ & 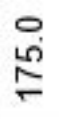 & $\begin{array}{l}0 \\
\infty \\
\stackrel{0}{*}\end{array}$ & 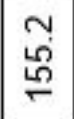 & $\stackrel{\sigma}{\stackrel{\sigma}{N}}$ & & & & \\
\hline & 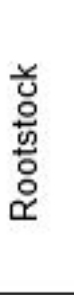 & & & 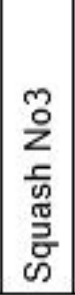 & 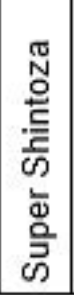 & $\begin{array}{l} \pm \\
0 \\
0\end{array}$ & 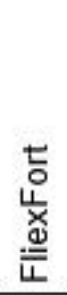 & 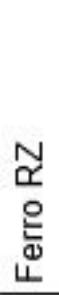 & $\begin{array}{l}5 \\
8 \\
0 \\
5 \\
\Sigma\end{array}$ & 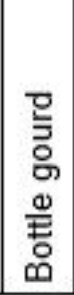 & 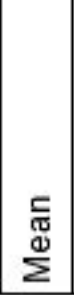 & $\begin{array}{l}0 \\
Z\end{array}$ & $\begin{array}{l}\sum \\
0 \\
0 \\
0 \\
0 \\
0 \\
ن \\
ن\end{array}$ & 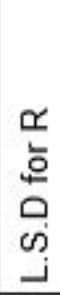 & $\begin{array}{l}\alpha \\
x \\
\sum \\
0 \\
0 \\
0 \\
0 \\
0 \\
0 \\
0\end{array}$ \\
\hline
\end{tabular}


M.H. Zaki, et al.,

Table (6): Effect of grafting methods onto different rootstocks on melon shoot fresh weights (g) during the two studied seasons

\begin{tabular}{|l|c|c|c|c|c|c|c|c|}
\hline \multirow{2}{*}{ Rootstock } & \multicolumn{5}{|c|}{ Shoot fresh weights (g) after 60 day from transplanting } \\
\cline { 2 - 9 } & \multicolumn{4}{|c|}{ Grafting method } & \multicolumn{3}{c|}{ Grafting method } \\
\cline { 2 - 9 } & \multicolumn{3}{|c|}{ First season } & \multicolumn{3}{c|}{ Second season } \\
\cline { 2 - 9 } & HIG & SG & TAG & Mean & HIG & SG & TAG & Mean \\
\hline Squash No3 & 123.5 & 127.7 & 128.3 & 126.5 & 125.7 & 125.4 & 122.6 & 124.6 \\
\hline Super Shintoza & 125.9 & 126.7 & 121.4 & 124.7 & 126.6 & 125.7 & 122.3 & 124.9 \\
\hline Coplt & 127.9 & 125.0 & 120.7 & 124.5 & 125.4 & 128.4 & 122.4 & 125.4 \\
\hline FliexFort & 125.4 & 129.4 & 122.4 & 125.7 & 125.9 & 126.5 & 122.5 & 125.0 \\
\hline Ferro RZ & 128.7 & 127.4 & 122.6 & 126.2 & 125.9 & 125.7 & 122.5 & 124.7 \\
\hline Nun 6001 & 126.6 & 125.7 & 122.3 & 124.9 & 126.5 & 128.1 & 123.3 & 126.0 \\
\hline Bottle gourd & 120.3 & 120.3 & 119.3 & 120.0 & 122.1 & 123.0 & 122.4 & 122.5 \\
\hline Mean & 125.5 & 126.0 & 122.4 & & 125.4 & 126.1 & 122.6 & \\
\hline NG & & & & 121.3 & & & & 111.4 \\
\hline L.S.D for GM & & & & 3.0 & & & & 2.8 \\
\hline L.S.D for R & & & & 3.3 & & & & 3.1 \\
\hline L.S.D for GM $\times$ R & & & & 3.2 & & & & 2.6 \\
\hline
\end{tabular}

HIG: Hole insertion grafting SG: Splice grafting TAG: tongue-approach grafting NG: no-grafting L.S.D (0.05) GM: for grafting methods L.S.D (0.05) R: for Rootstocks

L.S.D (0.05) GM $\times$ R : for interaction grafting methods $\times$ Rootstocks

the promoted vigor and vegetative growth of grafted melon could be explained by existing resistance to soil borne diseases (Lee, 1994), increasing water and plant nutrition uptake (Rivero et al., 2003), augmented endogenous hormone production (Zijlstra et al., 1994), tolerance to low soil temperature (Den Nijs, 1981) and salinity tolerance in the rootstocks (Rivero et al., 2003).

Concerning the effect of grafting method- rootstock interaction data showed that grafting melon in the hole insertion grafting method and splice grafting method onto Squash No3, Super Shintoza, Coplt, FliexFort, Ferro RZ and Nun 6001 rootstocks were the most superior in the respect of effect on vegetative growth performance of grafted plant followed by tongue approach grafting method while grafting on the local Bottle gourd gave the lowest values of these characteristics in all studied grafting methods.

\subsection{Fruit characteristics}

The variation in fruit characteristics [fruit length, fruit diameter, fruit weight and total soluble solids (TSS \%)] of grafted melon seedlings onto different rootstocks are shown in Table (7). Data indicate that the grafting methods were effective only on fruit weight and did not affect fruit length and fruit diameter. Data showed significant high fruit weight of grafting melon seedlings in hole insertion grafting method followed by splice grafting method with no significance differences between them while the lowest value were recorded on tongue approach grafting method during the two studied seasons. 


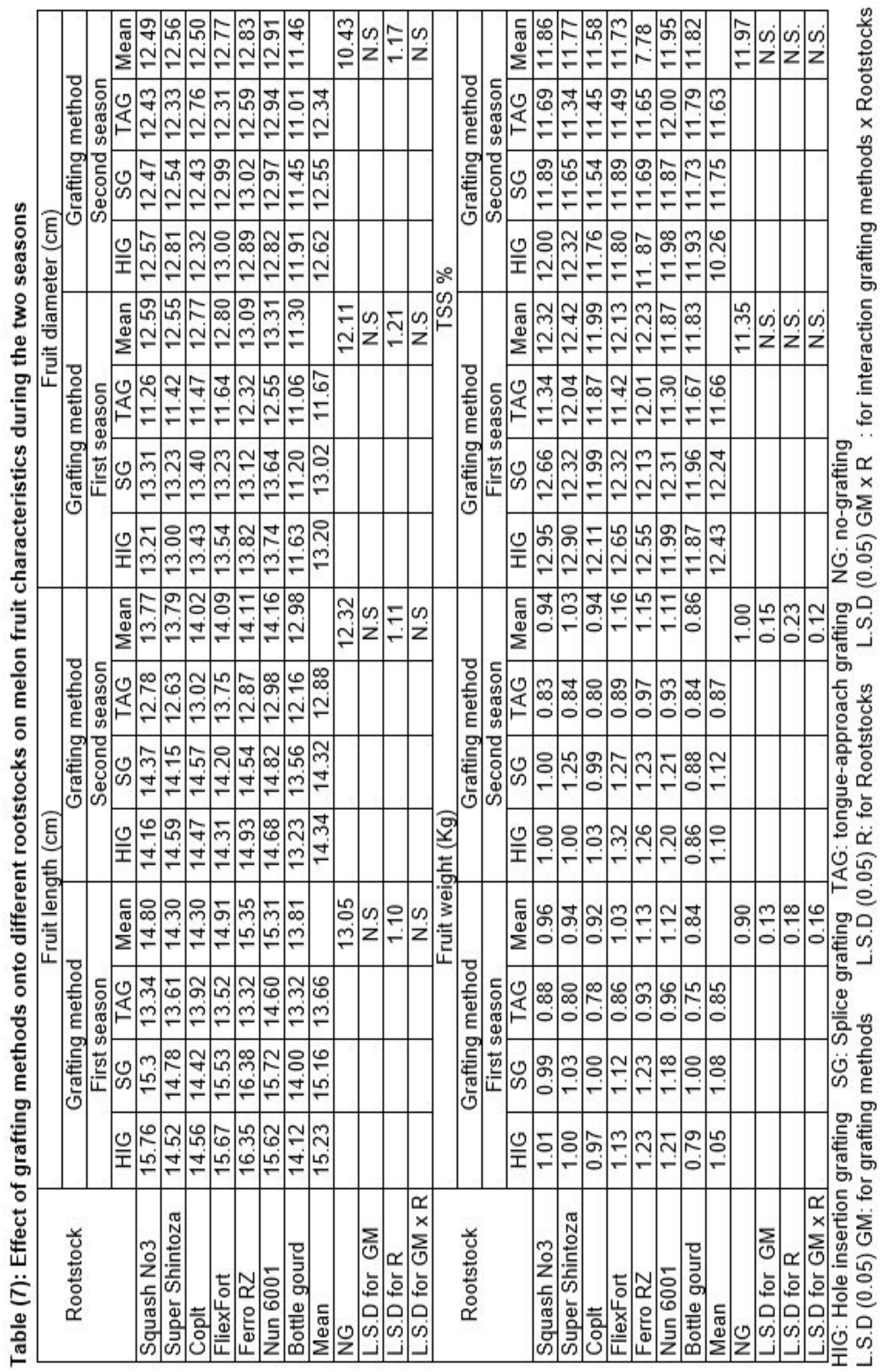


Results indicate that grafting melon plants onto Fliex Fort, Ferro RZ and Nun 6001 interspecific rootstocks hybrids caused significant increase in fruit length, fruit diameter and fruit weight without significant differences between them, while grafting onto local Bottle gourd gave the lowest values. These results indicated that fruit length, diameter and weight of melon grafted are influenced by rootstock. These results agreed with Lee, (1994) who reported that the influences of rootstocks on fruit quality are vary greatly. Moreover, the data showed that the local Bottle gourd is unsuitable rootstock for the grafting of the melon (cultivar Hybrid London), where it resulted low of fruit characteristics. This result indicate that there are weak compatibility between the melon plants (cultivar Hybrid London) and the local Bottle gourd rootstock which may result in blocking the transport of photosynthesis from scion to rootstock for grafted melon, as reported by Stigter (1971). This can lead to poor fruit quality as reported by Andrews and Marquez, (1993); Edelstein et al. (2004); Lee, (1994) and Traka-Mavrona et al. (2000).

Data showed that there are no differences due to the grafting methodrootstock interaction on fruit length and fruit diameter on melon grafting plants. On the other hand results indicate that there are differences due to the grafting method- rootstock interaction on fruit weight of melon grafting plants. Data indicate that grafting melon plants in hole insertion grafting method and onto Fliex Fort and Ferro RZ rootstock showed the most supper effect on fruit weight of melon grafted plants compared with other rootstocks. This result is in agreement with those of Rouphael et al. (2010) who reported that grafting vegetable plants onto resistant rootstocks enhance whole plant biotic stress responses which lead to increase fruit quality size.

Concerning the effect of grafting melon on total soluble solids (TSS\%) data in Table (8) indicated that the all grafting methods, rootstocks and grafting method- rootstock interaction did not affect this character. These results agree with those of Cushman and Huan (2008) and Paroussi et al. (2007) who reported that TSS was not affected by grafting.

\subsection{Yield components}

The variations in yield components (early and total yield) of grafting melon seedlings due to the grafting methods onto different rootstocks are shown in Table (8). The results showed that all yield components of grafting melon varied depending on grafting method, rootstock and the combination between grafting method and rootstock. Data indicate that the yield components (early and total yield) were significantly enhanced in grafted melon seedlings compared to the un-grafted control plants. These results agree with those of Aounallah et al. (2002); Lee and Oda (2003); Rivero et al. (2003); Yetisir and Sari (2003); Edelstein et al. (2004) and Tarchoun et al. (2005) who reported that the grafting is the best agronomic interest for plant production. Also the results are in harmony with Bletos et al. (2003); Colla et al. (2006); King et al. (2010), Jang et al. (2008) and TrakaMavrona et al. (2000) who reported that grafting technique is effective directly on plant yield. Data showed higher early and total yield of grafting melon seedlings in hole insertion grafting method and splice grafting method with no significant differences between them while the lowest values were recorded with tongue approach grafting method during the two studied seasons. This result indicate that the hole insertion grafting method and splice grafting 


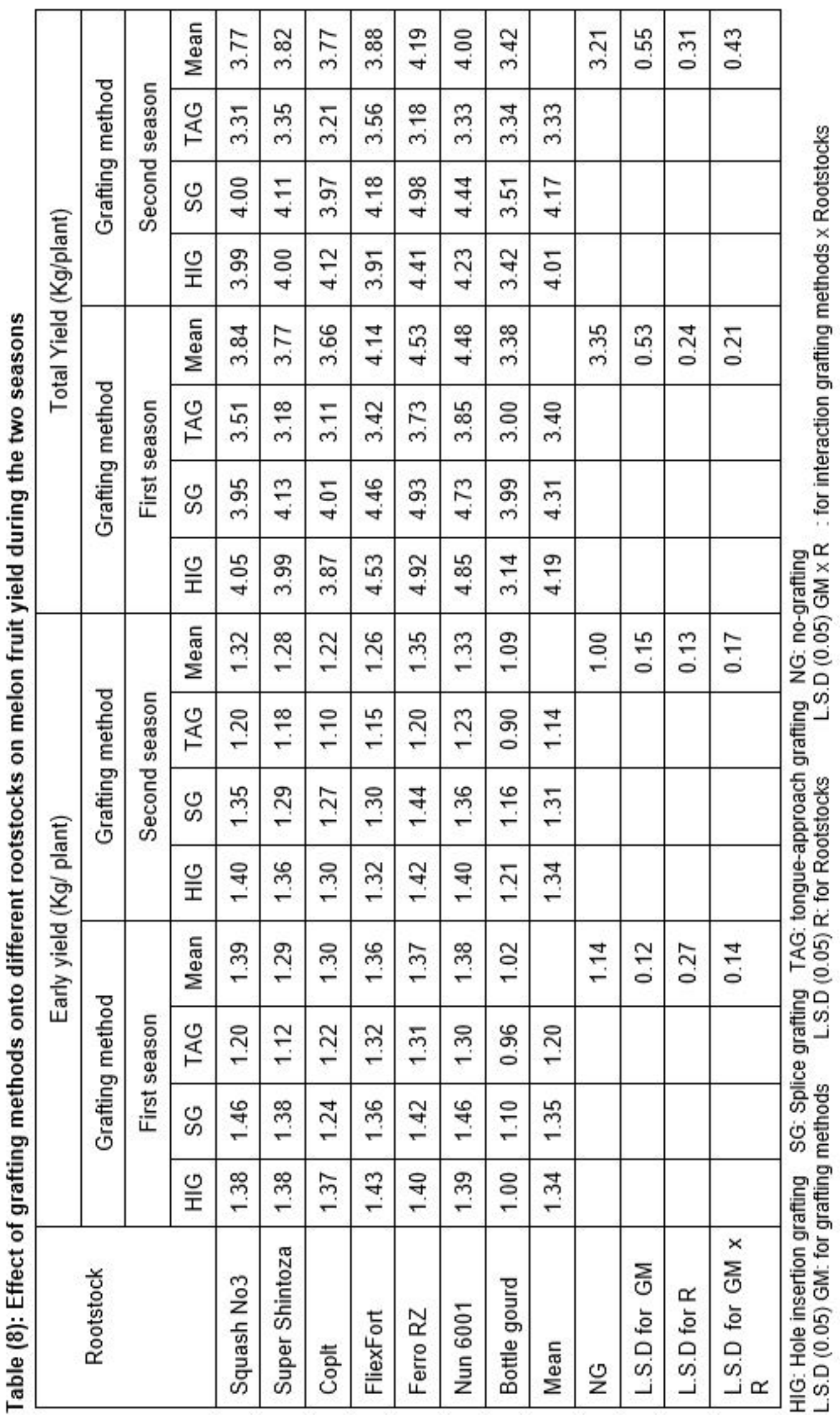


method are the best grafting technique in melon for increasing the early and total yield.

Results indicate that grafting melon plants onto Squash No3, Super Shintoza, Coplt, FliexFort, Ferro RZ and Nun 6001 rootstocks gave significant increase in early yield while the grafting onto Fliex Fort and Ferro RZ interspecific rootstocks hybrids caused significant increase in total yield. On the other hand grafting melon plants onto local bottle gourd caused the lowest early and total yield. The increased in early and total yield of grafted melon plants may be attributed to the superior effect of these rootstocks on length, diameter and average fruit weight in the present study. These results agree with those of Rouphael et al. (2010) who reported that grafting vegetable plants onto resistant rootstocks enhance whole plant biotic stress responses which lead to increase yield. Moreover, these results may be attributed to the strength roots of rootstocks that permit better growth. Many authors stated that a rootstock promoted higher yields in grafted plants (Chouka and Jebari, 1999; Nielsen and Kappel, 1996; Ruiz and Romero, 1999). These increases can be explained by an interaction of some or all of the following phenomena: increased water and plant nutrient absorption (Kato and Lou, 1989), augmented endogenous hormone production (Zijlstra et al., 1994), and enhanced scion vigor (Ito, 1991 and Leoni et al., 1990), resistance to soil pathogens (Edelstein et al, 1999 and Lee, 1994), tolerance to low soil temperature (Den and Smeets, 1987; Tachibana, 1989) and to salinity (Zerki and Parsons,1992). Moreover, the data showed that the local bottle gourd is unsuitable rootstock for grafting of the melon (cultivar Hybrid London), resulting in a weak vegetable growth, fruit quality, early and total yields. This result indicate that there are weak compatibility between the melon plants (cultivar Hybrid London) and the local bottle gourd rootstock which may result in blocking the transport of photosynthesis from scion to rootstock for grafted melon, as reported by Stigter (1971). This can lead to yield reduction, poor fruit quality, and even early plant collapse as reported by (Andrews and Marquez, 1993; Edelstein et al., 2004; Lee, 1994 and Traka-Mavrona et al., 2000).

Concerning the effect of grafting method- rootstock interaction data showed that grafting melon in hole insertion grafting method and splice grafting method onto Ferro RZ interspecific rootstocks hybrids caused significant increase in early and total yield. The highest yields which recorded in this study were not observed on all scion/rootstock combinations, suggesting that an accurate agronomic evaluation of the rootstock-scion combination is still necessary before using them on a commercial scale.

\section{Conclusions}

Grafting onto Squash No3, Super Shintoza, Coplt, FliexFort, Ferro RZ and Nun 6001 rootstocks are suitable method for commercial melons production under greenhouse conditions in Egypt where it provides sufficient protection against Fusarium oxysporum and Verticillium albo-atrum especially. The results showed that the survival rate of plants grafted onto these rootstocks were extremely high. In this respect it could be recommended that grafting melon seedlings by hole insertion and splice grafting methods onto Fliex Fort, Ferro RZ and Nun 6001 rootstocks tolerance to Fusarium and Verticilium wilt which closely related to gave vigor growth, higher yield under greenhouse conditions without exhibiting any 
detrimental effects on fruit quality of the cultivar used as scion.

\section{Acknowledgments}

We would like to thank Agriculture Development Programme (Created to support research and applied projects and campaigns of extension), Ministry of Agriculture and Land Reclamation of Egypt for offering their fund to the project "Grafting techniques to improve production and to solve the problems in melon" and their supporting of this study.

\section{REFERENCES}

Andrews, P.K. and C.S. Marquez (1993). Graft incompatibility. Horticultural Reviews 15:183-218.

Aounallah, S., H. Jebari and M. El Mahjoub (2002). Study of watermelon grafted to Fusarium oxysporum f. sp. niveum and F. solani f. sp. Cucurbitae. Annales de I, INRAT, 75; 191-204 (In French).

Bekhradi, F., A. Kashi and M. Delshad (2011). Effect of three cucurbits rootstocks on vegetative and yield of 'Charleston Gray' watermelon, International Journal of Plant Production 5 (2), April 2011. ISSN: 1735-6814 (Print), 1735-8043

Besri, M. (2008). Cucurbits grafting as alternative to methyl bromide for cucurbits production in Morocco. Proceedings of the 14th International Research Conference on Methyl Bromide Alternatives and Emissions Reduction, Orlando, pp. 60-61.

Biles, C.I., R.D. Martyn and H.D. Wilson (1989). Isoenzymes and general proteins from various watermelon cultivars and tissue types. HortScience, 24: 810 - 812.

Bithell, S. L., B. Condè, M. Traynor and E. C. Donald (2012). Grafting for soilborne disease management in Australian vegetable production systems - a review. Australasian Plant Pathology Society Inc, DOI 10.1007/s13313-012-0183-x
Bletos, F., C. Thanassoulopoulos and D. Roupakias (2003). Effect of grafting on growth, yield and verticillium wilt of eggplant. HortScience 38:183-186.

Boughalleb, N., M. Mhamdi, B. El Assadi, Z. El Bourgi, N. Tarchoun and M.S. Romdhani (2008). Resistance evaluation of grafted watermelon (Citrullus lanatus L.) against fusarium wilt and fusarium crown and root rot. Asian Journal of Plant Pathology 2 (1): 24-29.

Chouka, A.S. and H. Jebari (1999). Effect of grafting on watermelon on vegetative and root development, production and fruit quality. Acta Hort. 492:85-93.

Colla, G., Y. Rouphael, M. Cardarelli, D. Massa, A. Salerno and E. Rea (2006). Yield, fruit quality and mineral composition of grafted melon plants grown under saline conditions. J. Hort. Sci. Biotechnol., 81: 146-152.

Cushman, K.E. and J. Huan (2008). Performance of four triploid watermelon cultivars grafted onto five rootstock genotypes: yield and fruit quality under commercial growing conditions. Proc IVth IS on Seed, Transplant and Stand Establishment of Hort. Crops. Acta Hort. 782, ISHS.

Dau, V.T., L.W. Burgess, L.T. Pham, H.T. Phan, H.D. Nguyen, T.V. Le. and D.H. Nguyen (2009). First report of Fusarium wilt in watermelon in Vietnam. Australasian Plant Disease Notes 4, 1-3.

Den Nijs, A.P.M. and L. Smeets (1987). Analysis of difference in growth of cucumber genotypes under low light conditions in relation to night temperature. Euphytica 36:19-32.

Den Nijs, A.P.M. (1981). The effect of grafting on growth and early production of cucumbers at low temperature. Acta Hort. 118, 57-64.

Edelstein, M., R. Cohen, Y. Burger and S. Shriber (1999). Integrated management of sudden wilt in melons, caused by Monosporascus cannonballus, using grafting and reduced rates of methyl bromide. Plant Disease 83:1442-1445. 
Edelstein, M., Y. Burger, C. Horev, A. Porat, A. Meir and R. Cohen (2004). Assessing the effect of genetic and anatomic variation of Cucurbiat rootstocks on vigour, survival and yield of grafted melons. J. Hortic. Sci. Biotechnol, 79 (3): 370-374.

Gomez, K. A. and A. A. Gomez (1984). Statistical procedures for agricultural research, 2 nd ed. John Wiley and Sons. New York, 680 pp.

Heo, Y.C. (1991). Effects of rootstocks on exudation and mineral elements in different parts of oriental melon and cucumber. MS. Thesis, Kyung Hee Univ., Seoul, Korea.

Ito, T. (1991). Present state of transplant production practices in Japanese Horticultural Industry. In: Kurata,

Jang, Y.A., Y.Y. Cho, H.C. Rhee and Y.C. Um (2008). Effects of rootstock and night temperature on the growth and yield of grafted pepper. J. Kor. Soc. Hort. Sci. 49:63-71.

Kato, T. and H. Lou (1989). Effect of rootstocks on yield, mineral nutrition and hormonal level in xylem sap in eggplant. J. Jpn. Soc. Hortic. Sci. 58:345-352.

Kesevan, V. and B. Chounhury (1977). Screening for resistance to Fusarium wilt of tomato. Sabrao Journal. 9 (1) 57-65, (1977).

King, S.R., A.R. Davis, X. Zhang and K. Crosby (2010). Genetics, breeding and selection of rootstocks for Solanaceae and Cucurbitaceae. Sci. Hort. 127, 106111.

Lee, J.M. (1994). Cultivation of grafted vegetables I. Current status, grafting methods, and benefits. HortScience, 29(4): 235-239.

Lee, J.M. and M. Oda (2003). Grafting of herbaceous vegetable and ornamental crops. Horticultural Reviews 28, 61-125.

Lee, J.M., H.J. Bang and H.S. Ham (1998). Grafting of vegetable. J. Japan. Soc. Hort. Sci. 67, 1098-1114.
Leonardi, C. and D. Romano (2004). Recent issues on vegetable grafting. Acta Hort. 631, 163-174.

Leoni, S., R. Grudin, A. M. Cadinu, B. Madeddu and M.G. Garletti (1990). The influence of four rootstocks on some melon hybrids and a cultivar in greenhouse. Acta Hort., 287: 127-134.

Martyn, R.D. and T.R. Gordon (1996). Fusarium wilt of melon, T.A. Zitter, D.L. Hopkins, C.E. Thomas, eds., Compendium of Cucurbit Diseases. APS Press, St. Paul, Minn, 1996, pp. 14-15.

Nielsen, G. and F. Kappel (1996). Bing sweet cherry leaf nutrition is affected by rootstocks. Hort. Science 31:1169-1172.

Oda, M. (1999). Grafting of vegetables to improve greenhouse production. Food and Fertilizer Technology Center, Extension Bulletin. 480, 1-11.

Oda, M., K. Tsuji and H. Sasaki (1993). Effect of Hypocotyl morphology on survival rate and growth of cucumbers seedlings grafted on cucurbita spp. Jap. Agric. Res. Quart. 26, 259-263.

Oda, M., M. Dosia, H. Ikeda and $\mathrm{H}$. Furukawa (2000). Causes of low survival in cucumber (Cucumis sativus) plants grafted on to pumpkin (Cucurbita moschata) rootstocks by horizontal-cut grafting at the center of the hypocotyls. Sci. Res. Agric. Biol. Sci. Osaka Pref. Univ. 53, 1-5.

Paroussi, G. F., Bletsos G.A. Bardas J.A. Kouvelos and A. Klonari (2007). Control of Fusarium and Verticillium wilt of watermelon by grafting and its effect on fruit yield and quality. Proc. IIIrd Balkan Symp. on Veg. and Potatoes. Acta Hort. 729, ISHS.

Rivero, R.M., J.M. Ruitz and L. Romero (2003). Role of grafting in horticultural plants under stress conditions. J. Food Agr. Environ., 1: 70-74.

Rouphael, Y., Schwarz, D., Krumbien and G. Colla (2010). Impact of grafting on product quality of fruit vegetables. Scientia Hort. 27, 172- 179. 
Ruitz, J.M., A. Belakbir, A. Lopez-Cantarero and L. Romero (1997). Leafmacronutrient content and yield in grafted melon plants: A model to evaluate the influence of rootstock genotype. Scientia Hortic., 71: 227-234.

Ruiz, J.M. and L. Romero (1999). Nitrogen efficiency and metabolism in grafted melon plants. Sci. Hortic. 81:113-123.

Sakata, Y., T. Ohara and M. Sugiyama (2008). "The history of melon and cucumber grafting in Japan." Acta Horticulturae 767:217-228.

Stigter, H.C.M. (1971). Some aspects of the physiological functioning of the graft muskmelon/Cucurbita ficifolia. Pflanzenphysiologie, Bd. 65:223-231.

Tachibana, S. (1989). Respiratory response of detached root to lower temperatures in cucumber and figleaf gourd grown at $20 \square$ C root temperature. J. Jpn. Soc. Hortic. Sci. 58:333-337.

Tarchoun, N., N. Boughalleb and A. El. Mbarki (2005). Agronomic evaluation of nine Cucurbit rootstocks and watermelon grafted (Citrullus lanatus). Revue de I, INRAT, 20 (20): 125- 140.
Traka-Mavrona, E., M. Koutsika-Sotiriou and T. Pritsa (2000). Response of squash (Cucurbita spp.) as rootstock for melon (Cucumis melo L.). Sci. Hortic.83:353362.

Yetıs, ır, H. and N. Sari. (2003). Effect of hypocotyl morphology on survival rate and growth of watermelon seedlings grafted on rootstocks with different emergence performance at various temperatures. Turk. J. Agric. For. 28:231237.

Yetıs, Ir H., N. Sari and S. Y"ucel (2003). Rootstock Resistance to Fusarium Wilt and Effect on Watermelon Fruit Yield and Quality. Phytoparasitica 31(2)

Zerki, M. and L.R. Parsons (1992). Salinity tolerance of citrus rootstocks: Effects of salt on root and leaf mineral concentrations. Plant Soil 147:171-181.

Zijlstra, S., S.P.C. Groot and J. Jansen (1994). Genotypic variation of rootstocks for growth and production in cucumbers, possibilities for improving the root system by plant breeding. Scientia Hortic., 56: 185-196. 


\title{
تقنية التطيم على أصول القرعيات للسيطرة على الأمراض التي تنتقل عن طريق التربة وتعزيز السلوك الإنتاجي للثمام (كوكوميس ميلو) في مصر الترات
}

\author{
ميلاد حلمى زكى (1) ، تماضر جمعة عبد الرحمن (2) ، فهيمة هلال أيوب(1)

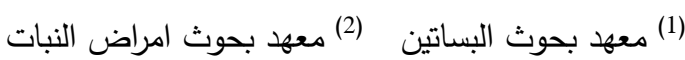

الملخص

تم إجراء تجربتين في الموسمين المتعاقبين 2016/2015 و 2017/2016 خلال نشاط مشروع "تقنية التطعيم لتحسين الإنتاج وحل مشاكل الثمام" تحت الصوب البلاستيكية من خلال دعم برنامج التتمية الزراعية في مصر .

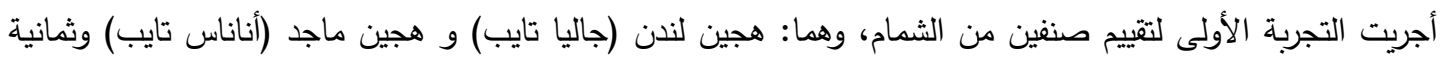

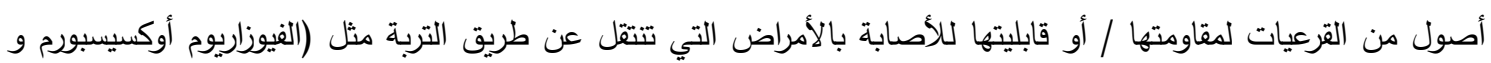

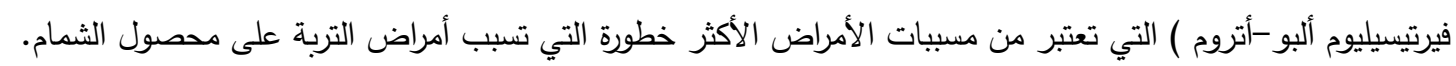

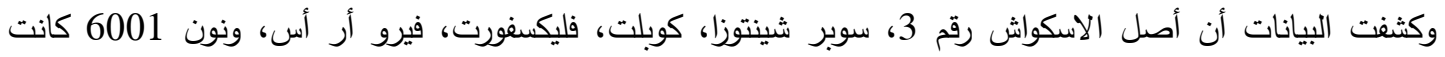

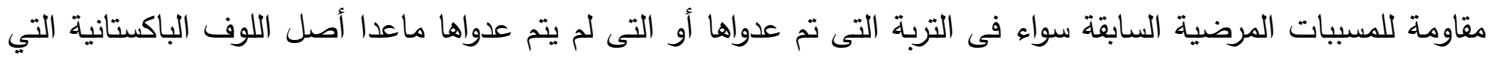

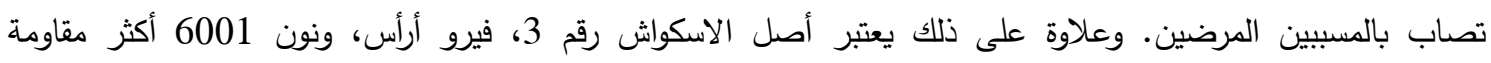

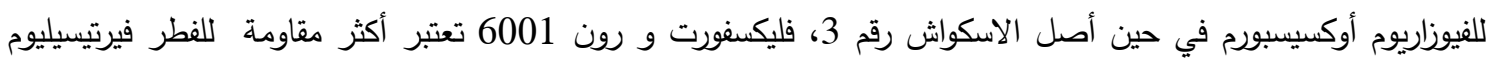

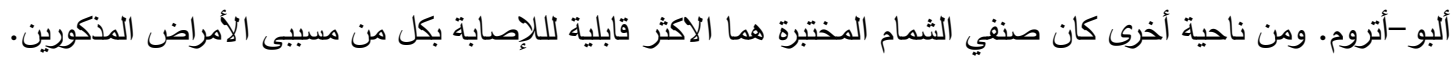
أجريت التجربة الثانية لدقارنة تأثير كل من الأصول المقاومة السابقة وثلاثة طرق للتطعيم (التطعيم بالثقب، التطعيم

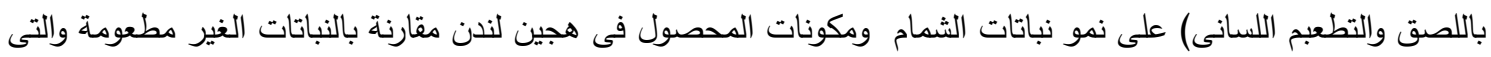
تستخدم ككنترول. وسجلت أعلى نسبة نجاح من شتلات الثمام المطعومة في طريقة التطعيم اللسانى يتبعها طريقة التطعيم باللصق وطريقة

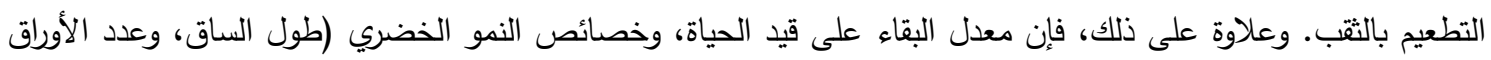

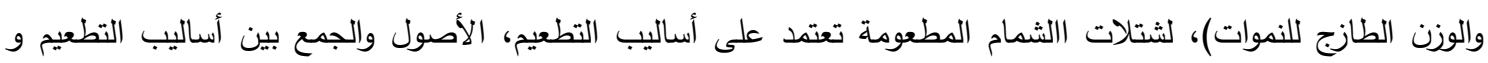

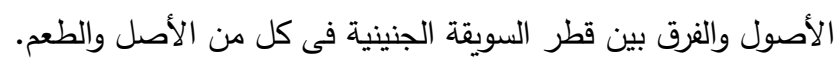

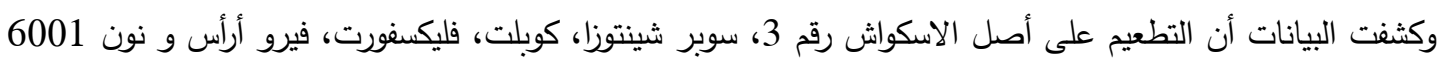

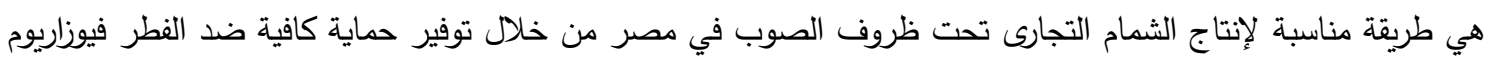

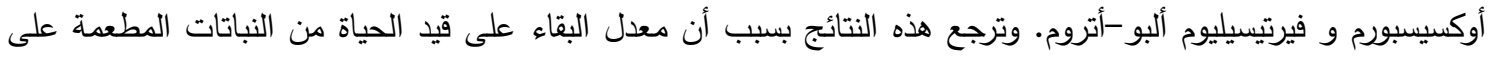

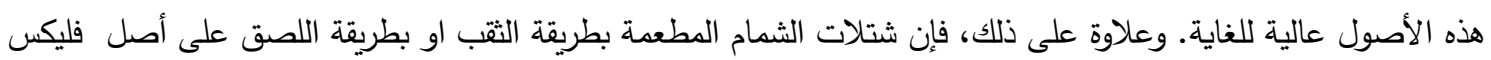

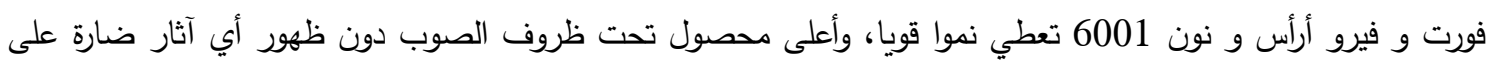
جودة ثمار الشمام لصنف هجين لندن.

أسماء السادة المحكمين

أ.د/ محمد محمد بيومى عمار كلية الزراعة قسم النبات الزراعى ( أمراض النبات) - جامعة المنوفية

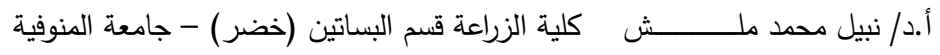


